\title{
Socio-cultural Condition of South Punjab: A Case of Muzaffargarh District
}

\author{
Hafiz Muhammad Fiaz \\ Saraiki Area Center BZU, Multan. \\ Email: fiaz.muhammad1@gmail.com \\ Dr. Sohail Akhtar \\ Department of History Ghazi University, D.G. Khan. \\ Email: sohailakhtar252@gmail.com \\ Ayaz Ahmad Rind \\ Ph.D Scholar, IUB, Bahawalpur. \\ Email: ayazahmadayaz00@gmail.com
}

Received on: 05-10-2021

Accepted on: 07-11-2021

\begin{abstract}
Muzaffargarh is located between the two rivers Indus and Chenab. People of the district have a simple and traditional culture. Saraiki is the major language of the district. Agriculture is considered the major occupation of the people in the district. This paper primarily deals with the socio-cultural development in Muzaffargarh District. Socio-cultural aspects of people are connected with the life of the people and it always considered important regarding socio-political and economic norms, traditions and customs of the people of any region. The region remained a cradle of civilizations in the past. The socio-cultural and political condition of the people almost resembles in the entire region of South Punjab with some minor differences. Only religion is the key factor in this perspective. To analyze the entire region a small region of the province Muzaffargarh District is a micro level study as a model to explore the above subject. Although Muzaffargarh District is considered a backward district of the Punjab in Pakistan. After the emergence of Pakistan we have looked a remarkable change in socio-political development as owing to the changes in the people, their population, education, dress, occupation their religious thoughts and their ways of life and political representation. This paper is an attempt to highlight the socio-cultural development in Muzaffargarh.
\end{abstract}

Keywords: Punjab, Muzaffargarh, District, Region, Social, People, Development, etc.

\section{Introduction}

Muzaffargarh is one of the southern district of Punjab located between Sindh and Chenab. The town was built by Nawab Muzaffar Khan Sadozai the ruler of Multan in 1794. The region faced many political ups and downs in the history. After Sadozai rule it was governed by Sikh 
Vol. II, Issue 3, Oct - December 2021

ISSN No: (ONLINE): 2710-043

www.irjei.com
International Research Journal of Education and Innovation

ISSN No: ISSN (PRINT): 2710-0448

DOI: https://doi.org/10.53575/irjei.v2.03(21)2.15-34

Socio-cultural Condition of South Punjab: A Case of Muzaffargarh District

and British respectively. With the annexation of Punjab it announced as a district in 1849. The region is mostly considered as underdeveloped during the colonial era while Barons and Land lords were the upper class of the society with political dominancy because literacy rate was very low and poverty was also a major factor in the social and political uplift for the people. After the emergence of Pakistan in 1947, Government tried to uplift the society through different reforms. The paper explores the socio-political development of the people which is considered a reflection of Punjab.

\section{Research Methodology}

To research on socio-cultural history is not an easy job and historic method of research has been adopted to complete this topic. With the help of various research tools as documentary and non-documentary sources have been used with all primary and secondary sources.

\section{Review of Literature}

Literature review is the basic component of any research and it is very unfortunate that thee local writers and intellectuals did not work on its social condition, only authentic information about the people of the district is the census reports and district gazetteer before the emergence of Pakistan. Due to the shortage of documents, census reports and gazetteer are very important and might help for the social history of the people of the district of Muzaffargarh. The most concern literature is based on Provincial Gazetteer, Census Reports of India, District Census Reports, Revenue Reports, Elections Record, and Educational Record. With official data books as Tareekh Makhzan-e-Punjab, Tareekh-e-Multan, Tareekh-e-Dera Ghazi Khan, Tareekh-e-Muzaffargarh, Tareekh Layyah have been consulted to complete this research.

\section{Discussion}

Muzaffargarh is a historical city located in the middle of two rivers in the Indus Valley. If one looks at the geographical position of Muzaffargarh, one can estimate how important this area is. Its western border is subject to the stormy waves of the Indus River on one side and Chenab in the east on the other. While the area bears witness to its antiquity in the form of river crossings, the living evidence of which is large sand dunes, the area is also famous for its fertility with lush green fields and orchards. Muzaffargarh represents itself whether it is a scientific or literary forum or a question of economic and social development. Politically too, this region has been the hub of important movements of the subcontinent and not only prominent personalities from here took part in the struggle for independence of Pakistan and faced prison of jail, after the establishment of Pakistan, the governor and the chief minister, thanks to the political position of the area. ${ }^{1}$

Whether it is the district board elections or Fatima Jinnah's victory from Muzaffargarh in the Awami League dictatorship, it is a proof of the political consciousness of the regional residents. This area has a historic role in welfare affairs. The welfare services of Sardar Kode Khan Jatoi and the establishment of Anjuman-e-Islamia by Abdul Hameed Dasti are the achievements of a time when such humanitarian work was not even imagined in Europe and no NGOs. The establishment of schools, hospitals and orphanages are examples of personal services that have become the hallmark of this district. Contributed to the full development 
Vol. II, Issue 3, Oct - December 2021

ISSN No: (ONLINE): 2710-043

www.irjei.com
International Research Journal of Education and Innovation

ISSN No: ISSN (PRINT): 2710-0448

DOI: https://doi.org/10.53575/irjei.v2.03(21)2.15-34

\section{Socio-cultural Condition of South Punjab: A Case of Muzaffargarh District}

of the nation. Similarly, Sufis and intellectuals are not far behind in regional development. ${ }^{2}$ Among these Sufis are Hazrat Pir Dawood Jahanian, Alam Pir, Abdullah Shah Bukhari, Ghous Hamza Pak. All of them played a role in lighting the candles of Islam and spirituality. Khan also burnt this area from one place. Therefore, Muzaffargarh is a very unique area historically and culturally with a special soil and a small effort to highlight its regional significance by taking a bird's eye view of its history. Here is a summary of my humble attempt to write the history of Muzaffargarh in chronological order. ${ }^{3}$

Muzaffargarh is an ancient literary and historical site. It is said that the Hindu holy books Ramayana, Mahabharata and Vedic sciences were written sitting on the banks of the river Indus. Apart from this orthodoxy, it is also clear that in every era this area has been under the control of invaders. Due to which the population of this region continued to migrate. Later this area remained in the possession of the local Hindu rulers. During the fall of the Delhi Empire, the region was ruled by several families, including Nahar, Lingah, Baloch, Durrani, Saduzai, Sikhs and the British.

The word social means people. The study of the people in the society, in other words the study of their lives, ways of living and the standard of life that how people live in an area. It also means the condition of the society. As well as Culture is a composite identity and is made up of some elements like as behaviour patterns of the people, artifices and creative achievements \& religious system of the people. The district Muzaffgarh is situated between the rivers Indus and Chenab.During the fifteenth century, the river Indus had been flowing in the middle of present Thal.Layyah and Muzaffargarh were situated in the West at that time. Now they are located in the East. In 1778 river Indus changed its way. ${ }^{4}$ The social condition of the people was very unbelievable before 1960. Deputy Commissioner Masood has described the social condition of the people as under; "In district Muzaffargarh landlords and barons were the owner of the maximum agricultural land. They cultivated their lands through tenants. The tenants cultivated the land. But they had no authority to make a good planning about the cultivation against the will of the landlords and barons. Landlords and barons were cruel and they occupied the land of poor illegally. The Hamdani Syeds of Budh were very cruel and they tyrannized the poor people and sent them to Sindh. The district was totally under the control of the landlord and barons. These land lords and barons very cruel to the poor subjects." ${ }^{5}$ The total area of district was 5613 square miles in 1981\& The total population of Muzaffargarh district was 21, 64,253 according to the census of 1981 with an intercensal percentage increase of $40.1 \%$ since 1972 when it was 1,564995 souls the average annual growth rate was 3.4 per cent during this period. The population density of persons per square kilometer as against 182 persons observed in 1981 indicating a fast growth rate of the district. According to the census report 1981 Layyah, Muzaffargarh, Alipur and Kotadu are prospectively big as a population. 6

Population of the district since 1881-1981.

\begin{tabular}{|c|c|c|c|c|c|c|}
\hline Year & Male & Female & Total & Density & Increase & Sex.Ratio \\
\hline 1881 & 240190 & 201037 & 441227 & 79 & - & 1080 \\
\hline 1891 & 267574 & 226340 & 493914 & 80 & 10.7 & 1165 \\
\hline 1901 & 285976 & 241705 & 527681 & 95 & 6.39 & 1165 \\
\hline 1911 & 308350 & 261111 & 569461 & 102 & 7.9 & 1153 \\
\hline
\end{tabular}


Vol. II, Issue 3, Oct - December 2021

ISSN No: (ONLINE): 2710-043

www.irjei.com
International Research Journal of Education and Innovation ISSN No: ISSN (PRINT): 2710-0448 DOI: https://doi.org/10.53575/irjei.v2.03(21)2.15-34

Socio-cultural Condition of South Punjab: A Case of Muzaffargarh District

\begin{tabular}{|l|c|c|c|c|c|c|}
\hline \hline & & & & \\
\hline 1921 & 308605 & 259873 & 568478 & 102 & -2 & 1158 \\
\hline 1931 & 324764 & 266611 & 591375 & 108 & 4.0 & 1185 \\
\hline 1941 & - & - & 712849 & 127 & 20.5 & 1193 \\
\hline 1951 & 403871 & 347379 & 751250 & 134 & 5.4 & 1163 \\
\hline 1961 & 530512 & 459366 & 989878 & 176 & 31.8 & 1154 \\
\hline 1972 & 846541 & 718354 & 1564895 & 278 & 58.8 & 1178 \\
\hline 1981 & 1145062 & 1019191 & 2164253 & 149 & 38.3 & 1146 \\
\hline
\end{tabular}

Population of District Muzaffargarh in 1951 was as under;

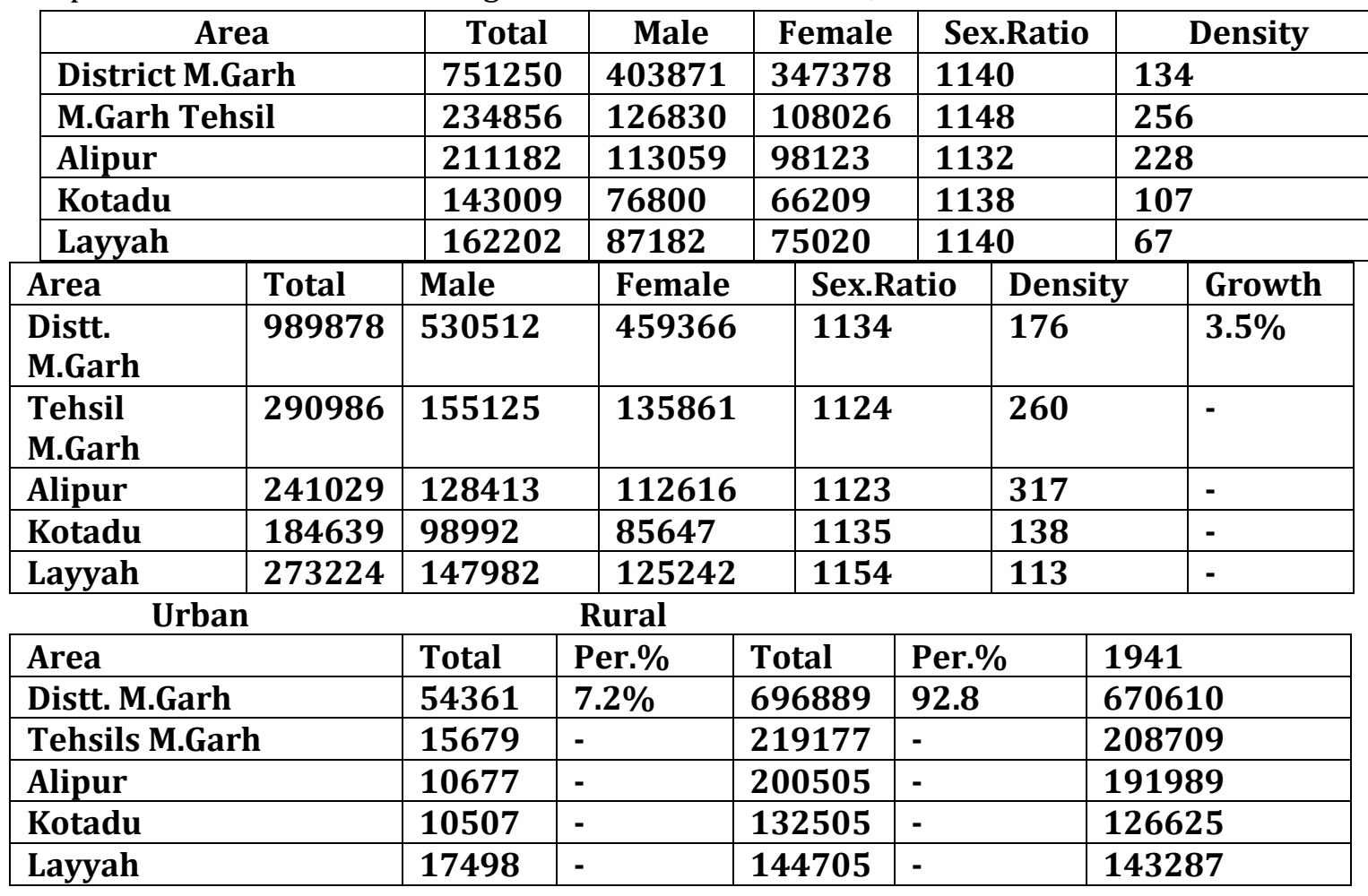

\section{Population In 1961}

Urban

Rural

\begin{tabular}{|l|c|c|c|c|c|c|c|c|}
\hline Area & Total & Male & Female & Per.\% & Total & Male & Female & Per.\% \\
\hline Distt & 72953 & 39009 & 33944 & 7.3 & 916925 & 491503 & 425422 & 92.7 \\
\hline $\begin{array}{l}\text { Tehsils } \\
\text { M.Garh }\end{array}$ & 19845 & 10654 & 9191 & - & 271241 & 144471 & 126670 & - \\
\hline Alipur & 11753 & 6258 & 5495 & - & 229276 & 122155 & 107121 & - \\
\hline Kotadu & 16180 & 8639 & 7541 & - & 168459 & 90353 & 78106 & - \\
\hline Layyah & 25175 & 13458 & 11717 & - & 248049 & 134524 & 113525 & - \\
\hline
\end{tabular}


Vol. II, Issue 3, Oct - December 2021

ISSN No: (ONLINE): 2710-043

www.irjei.com
International Research Journal of Education and Innovation ISSN No: ISSN (PRINT): 2710-0448 DOI: https://doi.org/10.53575/irjei.v2.03(21)2.15-34

Socio-cultural Condition of South Punjab: A Case of Muzaffargarh District

Population In 1972

\begin{tabular}{|c|c|c|c|c|c|c|c|c|c|}
\hline Area & \multicolumn{2}{|c|}{ Total } & Male & \multicolumn{2}{|c|}{ Female } & \multicolumn{2}{|c|}{ Sex.Ratio } & Density & Growth \\
\hline District.M.Garh & \multicolumn{2}{|c|}{1564895} & 846541 & \multicolumn{2}{|c|}{718354} & \multicolumn{2}{|c|}{1178} & 278 & 4.0 \\
\hline M.Garh Tehsil & \multicolumn{2}{|c|}{420514} & 227296 & \multicolumn{2}{|c|}{193218} & \multicolumn{2}{|c|}{1176} & 458 & 3.2 \\
\hline Alipur & \multicolumn{2}{|c|}{335707} & 182602 & \multicolumn{2}{|c|}{153105} & \multicolumn{2}{|c|}{1192} & 362 & 2.9 \\
\hline Kotadu & \multicolumn{2}{|c|}{313137} & 169207 & \multicolumn{2}{|c|}{143930} & \multicolumn{2}{|c|}{1175} & 233 & 4.6 \\
\hline Layyah & 495 & 37 & 267436 & 2281 & & & 72 & 204 & 5.2 \\
\hline \multicolumn{5}{|c|}{ Urban } & \multicolumn{5}{|c|}{ Rural } \\
\hline Area & Total & Male & $\begin{array}{c}\text { Femal } \\
\text { e }\end{array}$ & $\%$ & To & & Male & $\begin{array}{c}\text { Femal } \\
\text { e }\end{array}$ & $\%$ \\
\hline Distt. M.Garh & $\begin{array}{c}11988 \\
8\end{array}$ & 64726 & 55162 & $7.7 \%$ & 144 & 00 & $\begin{array}{c}76181 \\
5\end{array}$ & $\begin{array}{c}66319 \\
2\end{array}$ & $92.3 \%$ \\
\hline $\begin{array}{l}\text { Tehsils } \\
\text { M.Garh }\end{array}$ & 31923 & 17498 & 14425 & - & 388 & 91 & $\begin{array}{c}20979 \\
8 \\
\end{array}$ & $\begin{array}{c}17879 \\
3 \\
\end{array}$ & - \\
\hline Alipur & 21203 & 11550 & 9563 & - & 314 & 04 & $\begin{array}{c}17105 \\
2\end{array}$ & $\begin{array}{c}14345 \\
2\end{array}$ & - \\
\hline Kotadu & 24759 & 13162 & 11597 & - & 288 & 78 & $\begin{array}{c}15604 \\
5\end{array}$ & $\begin{array}{c}13233 \\
3\end{array}$ & - \\
\hline Layyah & 42003 & 22516 & 19487 & - & 453 & 34 & $\begin{array}{c}24492 \\
0\end{array}$ & $\begin{array}{c}20861 \\
4\end{array}$ & - \\
\hline
\end{tabular}

\section{Population in 1981}

\begin{tabular}{|c|c|c|c|c|c|c|}
\hline Area & Total & Male & Female & Sex.Ratio & Density & Growth \\
\hline Distt.M.Garh & 2164253 & 1145062 & 1019191 & 1146 & 138 & 3.9 \\
\hline M.Garh Tehsil & 574892 & 304985 & 269907 & 1121 & 241 & 3.7 \\
\hline Alipur & 473351 & 251328 & 222023 & 1131 & 197 & 4.1 \\
\hline Kotadu & 449493 & 237160 & 212333 & 1116 & 129 & 4.3 \\
\hline Layyah & 666517 & 351589 & 314928 & 1116 & 106 & 3.5 \\
\hline
\end{tabular}

\begin{tabular}{|l|c|c|c|c|c|c|c|c|}
\hline \multicolumn{4}{|c|}{ Urban } & \multicolumn{4}{c|}{ Rural } \\
\hline $\begin{array}{l}\text { Area } \\
\text { Mistt. }\end{array}$ & Total & Male & $\begin{array}{c}\text { Femal } \\
\mathbf{e}\end{array}$ & Per.\% & Total & Male & $\begin{array}{c}\text { Femal } \\
\text { e }\end{array}$ & Per.\% \\
\hline $\begin{array}{l}\text { Tehsils } \\
\text { Alipur }\end{array}$ & 1945458 & $\begin{array}{c}102873 \\
8\end{array}$ & $\begin{array}{c}91672 \\
0\end{array}$ & 89.8 & $\begin{array}{c}21879 \\
5\end{array}$ & 116324 & $\begin{array}{c}10247 \\
1\end{array}$ & 10.2 \\
\hline M.Garh & 510256 & 226174 & $\begin{array}{c}19951 \\
3\end{array}$ & - & 47664 & 25154 & 22510 & - \\
\hline Kotadu & 405771 & 214095 & $\begin{array}{c}19167 \\
6\end{array}$ & - & 43722 & 23065 & 20657 & - \\
\hline Layyah & 603745 & 318518 & 85522 & - & 62772 & 33071 & 29701 & - \\
\hline
\end{tabular}


Vol. II, Issue 3, Oct - December 2021

ISSN No: (ONLINE): 2710-043

www.irjei.com
International Research Journal of Education and Innovation ISSN No: ISSN (PRINT): 2710-0448 DOI: https://doi.org/10.53575/irjei.v2.03(21)2.15-34

Socio-cultural Condition of South Punjab: A Case of Muzaffargarh District

\begin{tabular}{|c|c|c|c|c|c|}
\hline & & 7 & & & \\
\hline \multicolumn{6}{|c|}{ Material Status of population } \\
\hline Year & Total & Married & Never-Married & Widowed & Divorced \\
\hline 1921 & - & $\begin{array}{l}113926 \\
118165 \\
\end{array}$ & $\begin{array}{l}172058 \\
110597 \\
\end{array}$ & $\begin{array}{l}19989 \\
12590 \\
\end{array}$ & - \\
\hline 1951 & $\begin{array}{l}\text { M-403871 } \\
\text { F-347378 } \\
\end{array}$ & $\begin{array}{l}157696 \\
145992 \\
\end{array}$ & $\begin{array}{l}230142 \\
184257 \\
\end{array}$ & $\begin{array}{l}15874 \\
15744 \\
\end{array}$ & $\begin{array}{c}157 \\
1385 \\
\end{array}$ \\
\hline 1961 & $\begin{array}{r}\text { M-530512 } \\
\text { F-459366 } \\
\end{array}$ & $\begin{array}{l}206845 \\
214011 \\
\end{array}$ & $\begin{array}{l}299318 \\
213331 \\
\end{array}$ & $\begin{array}{l}23074 \\
31186 \\
\end{array}$ & 1275838 \\
\hline 1972 & $\begin{array}{l}M-566121 \\
\text { F-463563 } \\
\end{array}$ & $\begin{array}{l}306521 \\
308610 \\
\end{array}$ & $\begin{array}{l}231703 \\
116552 \\
\end{array}$ & $\begin{array}{l}26756 \\
37423 \\
\end{array}$ & 1141 \\
\hline 1981 & $\begin{array}{r}\text { M-610495 } \\
\text { F-533735 }\end{array}$ & $\begin{array}{l}439087 \\
427665 \\
\end{array}$ & $\begin{array}{c}149552 \\
58891 \\
\end{array}$ & $\begin{array}{l}20712 \\
45306 \\
\end{array}$ & 11441873 \\
\hline
\end{tabular}

$*$ M for Male\& $\mathrm{F}$ for Female

\section{Important Urban Localities, their Population \& Area}

\begin{tabular}{|c|c|c|c|c|c|c|c|c|c|c|}
\hline Locality & 190 & 191 & $\begin{array}{l}19 \\
21\end{array}$ & 193 & $\begin{array}{l}194 \\
1\end{array}$ & 195 & $\begin{array}{l}196 \\
1\end{array}$ & 1972 & 1981 & $\begin{array}{l}\text { Ar } \\
\text { ea }\end{array}$ \\
\hline M.Garh M. C & $\begin{array}{l}401 \\
8\end{array}$ & 4387 & $\begin{array}{l}53 \\
86\end{array}$ & 6110 & 8265 & $\begin{array}{l}1127 \\
1\end{array}$ & $\begin{array}{l}1447 \\
8\end{array}$ & 24736 & 53192 & 2.0 \\
\hline Layyah M.C & $\begin{array}{l}754 \\
6 \\
\end{array}$ & 8173 & $\begin{array}{l}84 \\
76 \\
\end{array}$ & 9578 & $\begin{array}{l}1303 \\
7\end{array}$ & $\begin{array}{l}1491 \\
4\end{array}$ & $\begin{array}{l}1960 \\
8\end{array}$ & 33549 & 51482 & 4.5 \\
\hline Kotadu M.C & - & - & - & 4925 & 6960 & $\begin{array}{l}1050 \\
7\end{array}$ & $\begin{array}{l}1310 \\
7\end{array}$ & 21409 & 37479 & 1.5 \\
\hline Jotoi T.C & - & - & - & - & - & 4744 & 5384 & 8068 & 21422 & 0.5 \\
\hline Alipur T.C & $\begin{array}{l}278 \\
8\end{array}$ & 3312 & $\begin{array}{l}34 \\
34 \\
\end{array}$ & 3931 & 4829 & 5933 & 6369 & 8106 & 17592 & 1.5 \\
\hline Khangarh T.C & $\begin{array}{l}362 \\
1\end{array}$ & 3349 & $\begin{array}{l}31 \\
84\end{array}$ & 2863 & 4402 & 4408 & 5371 & 7187 & 11445 & 0.5 \\
\hline Karor T.C & $\begin{array}{l}324 \\
3\end{array}$ & 3503 & $\begin{array}{l}35 \\
39\end{array}$ & 3491 & 4696 & 2584 & 5567 & 8454 & 11290 & 3.0 \\
\hline Shehr Sultan T.C & - & - & - & - & - & - & - & 5029 & 8650 & 0.5 \\
\hline $\begin{array}{l}\text { Daira Din Panah } \\
\text { T.C }\end{array}$ & - & - & - & - & - & - & 3073 & 3350 & 6243 & 0.5 \\
\hline
\end{tabular}

There were 1632 Mauzas (a smallest revenue unit) in1981 of which 52 had population over 5 thousand. 527 had 1 to 5 thousand populations, 857 had two hundred to one thousand, and 196 had fewer than two hundred persons while 73 were un-inhabited.7 There are 1921 villages at present besides 705 colony Chaks in the district.. ${ }^{8}$ Detail of village is as under in the table.

Villages 
Vol. II, Issue 3, Oct - December 2021

ISSN No: (ONLINE): 2710-043

www.irjei.com
International Research Journal of Education and Innovation ISSN No: ISSN (PRINT): 2710-0448 DOI: https://doi.org/10.53575/irjei.v2.03(21)2.15-34

Socio-cultural Condition of South Punjab: A Case of Muzaffargarh District

\begin{tabular}{|l|c|c|c|c|c|c|c|}
\hline \hline Area & $\mathbf{1 8 8 1}$ & $\mathbf{1 9 0 1}$ & $\mathbf{1 9 3 1}$ & $\mathbf{1 9 5 1}$ & $\mathbf{1 9 6 1}$ & $\mathbf{1 9 7 2}$ & $\mathbf{1 9 8 1}$ \\
\hline District. M.Garh & 643 & 718 & 761 & 823 & 921 & 1673 & 1632 \\
\hline Tehsils M.Garh & 309 & 378 & 332 & 401 & 398 & - & - \\
\hline Alipur & 115 & 182 & 167 & 175 & 203 & - & - \\
\hline Kotadu & 116 & 140 & 147 & 148 & 143 & - & - \\
\hline Layyah & $* 103$ & $* 118$ & 115 & 159 & 177 & - & - \\
\hline
\end{tabular}

Population by Religion

\begin{tabular}{|c|c|c|c|l|c|c|c|c|c|c|}
\hline $\begin{array}{c}\text { Yea } \\
\mathbf{r}\end{array}$ & Total & $\begin{array}{c}\text { Musli } \\
\mathbf{m}\end{array}$ & $\begin{array}{c}\text { Hind } \\
\text { us }\end{array}$ & $\begin{array}{l}\text { Sche. } \\
\text { castes }\end{array}$ & $\begin{array}{l}\text { Chris } \\
\text { t. }\end{array}$ & $\begin{array}{c}\text { Bu } \\
\text { dh }\end{array}$ & $\begin{array}{c}\text { Sikh } \\
\text { Par } \\
\text { si }\end{array}$ & $\begin{array}{c}\text { Othe } \\
\text { rs }\end{array}$ & $\begin{array}{c}\text { Ahm } \\
\text { di }\end{array}$ \\
\hline $\begin{array}{c}190 \\
1\end{array}$ & $\begin{array}{c}5276 \\
81\end{array}$ & $\begin{array}{c}35017 \\
7\end{array}$ & $\begin{array}{c}5222 \\
1\end{array}$ & - & - & - & - & - & - & - \\
\hline $\begin{array}{c}192 \\
1\end{array}$ & $\begin{array}{c}5684 \\
78\end{array}$ & $\begin{array}{c}49336 \\
9\end{array}$ & $\begin{array}{c}6987 \\
8\end{array}$ & - & 356 & - & 4869 & - & 05 & - \\
\hline $\begin{array}{c}195 \\
1\end{array}$ & $\begin{array}{c}7512 \\
49\end{array}$ & $\begin{array}{c}75120 \\
6\end{array}$ & - & 24 & 19 & - & - & - & 19 & - \\
\hline $\begin{array}{c}196 \\
1\end{array}$ & $\begin{array}{c}9898 \\
78\end{array}$ & $\begin{array}{c}98664 \\
7\end{array}$ & 22 & 260 & 2949 & - & - & - & - & - \\
\hline $\begin{array}{c}197 \\
2\end{array}$ & $\begin{array}{c}1564 \\
895\end{array}$ & $\begin{array}{c}15571 \\
54\end{array}$ & 30 & 360 & 4000 & - & - & - & 3351 & - \\
\hline 198 & 2164 & 21490 & 594 & - & 1221 & 04 & 16 & 34 & 485 & 1852 \\
1 & 253 & 56 & & & 2 & & & & & \\
\hline
\end{tabular}

The district Muzaffargarh is a well-populated area of the country that's why different types of ethnic groups are living in the district. Some of them are local and a number of them are migrated groups. The most famous tribes and races are as under; Dasti, Khar, Qureshi, Jatoi, Hinjra, Langrial, Thahim, Gopang, Bukhari, Gilani, Rajpot, Jat and Arian. There are some migrant's families also like Shairwani, Rajpot, Sheikh and Qureshi. ${ }^{9}$ In Islam there is no superior all are the son of Adam (A.S). All the Muslims are equal. The noble one is that who is respectable before the God. "O people we created you from a man and woman and made your castes and tribes so that you may recognize each others. ${ }^{10}$ The word tribe means group of three or more than three person. ${ }^{11}$ In the encyclopedia Bertanica the word tribe is defined as "In cultural anthropology, theoretical type of human social organization based on small groups defined by tradition of common descent and having temporary or permanent political integration above the family level and shared language culture and ideology". ${ }^{12}$

\begin{tabular}{|l|l|}
\hline Jats & $\begin{array}{l}\text { Sials, Tahims, Chajra, Sumras, Prehars, Gorahas, Hinjras, and Makwals, Bhattis, } \\
\text { Dahas, Bhutas, Saho and Jhangales. }\end{array}$ \\
\hline Bloch & $\begin{array}{l}\text { Dasti, Jatoi, Mastoi, Sakhani, Ghazlani, Gurmani, Pitafi, chandia, Surhani. Lashari, } \\
\text { Gopang Gishkori. Qaisrani, Buzdar }\end{array}$ \\
\hline Syed & Bukhari, Naqvi, Rizvi, Kazmi, Mashahdi, Zaidi and Gillani \\
\hline Qureshi & Siddiqui, Hashmi, \\
\hline Rajput & Daha, Rangar, Dogar, Chohan, Joyah, Gujar, Bhatti, Panwar \\
\hline Other & Pathan Jhabel, Sheikh, \\
\hline
\end{tabular}


Vol. II, Issue 3, Oct - December 2021

ISSN No: (ONLINE): 2710-043

www.irjei.com
International Research Journal of Education and Innovation

ISSN No: ISSN (PRINT): 2710-0448

DOI: https://doi.org/10.53575/irjei.v2.03(21)2.15-34

Socio-cultural Condition of South Punjab: A Case of Muzaffargarh District

\section{Tribes \&Castes and their strength}

\begin{tabular}{|c|c|c|c|c|c|}
\hline Sr. No. & Caste & 1881 & 1891 & 1901 & 1921 \\
\hline 1 & Arain & 3991 & 8134 & 8999 & \\
\hline 2 & Awan & 626 & 2964 & 3232 & \\
\hline 3 & Bloch & 58399 & 68346 & 76586 & 108413 \\
\hline 4 & Jat & 109352 & 105738 & 117362 & 211191 \\
\hline 5 & Khoja & 714 & 1995 & 2424 & \\
\hline 6 & Khokhar & 951 & 4368 & 4020 & ---- \\
\hline 7 & Kumhar & 6621 & 6984 & 7204 & ---- \\
\hline 8 & Lohar & 1477 & 1907 & 1697 & ---- \\
\hline 9 & Mochi & 11102 & ---- & 12935 & --- \\
\hline 10 & Jolaha & 13623 & 12608 & 16090 & ---- \\
\hline 11 & Chorha & 11306 & 15058 & 4119 & --- \\
\hline 12 & Syed & ----- & ------ & ---- & 11222 \\
\hline 13 & Pathan & ----- & ----- & ---- & 3748 \\
\hline 14 & Qureshi & ---- & ----- & ----- & 4472 \\
\hline
\end{tabular}

The Jats own the largest are of the land ands they are spread over the entire district. Jats is the major tribe of the district and there are many stories about the Jats. Large number of groups of Jats is located in the district; some of them are Bhattis, Dahas, Bhutas, Saho and Jhangales. Mostly they are peasant in Muzaffargarh the well known branches of Jats are Sials, Tahims, Chajra, Sumras, Prehars, Gorahas, Hingras, and Makwals. In the economical point of view mostly they are agriculturist and they are cultivator in the district. The Jats call him zameendar or often as Jat. They work in the fields' dawn to dusk. Like men, women and children also work in the field's whole day. ${ }^{14}$

There are many stories are famous about the Jats, like as Mr. 0, Brien said in the Muslims, which are not Syed, Qureshi, Bloches, Pathan, these are called Jats by caste. Col. Tod, he called them the Scythian and Cunningham said Rajputs were Aryan and the Jats were from the Scythian race. ${ }^{15}$ Jats are usually content to cultivate his field and pay his revenue in peace and quietness if people let him do so; when he does go wrong he takes to anything from gambling to murder, with perhaps a preference for stealing other people's wives and cattle. A saying is famous about them; "The soil fodder, clothes, hemp, grass fiber and silk these six are best beaten and the seventh is the Jat. Jat, a Bhat, a caterpillar and a widow woman these four are best hungry. If they eat their full they do harm. The Jat like a wound is better when bond. In agriculture no other caste is equal than Jats. They are more experts than others in agriculture. Jats men, woman and children work whole day in the fields. The important branches of Jats are as. Thahim, Khar, Hinjra, Sayal, Jakhar, Khar, Bhutta, Budh ${ }^{16}$ It is said that the Rajputs are the sons of Rajas. They settle in the district. From Karnal and Gurdaspur. Many Jats tribes also claimed that they are Rajput. Elphinstone says that the Rajputs are belonged to the lunar race, which was lived between the Gunga and Jumna. The migrated from there and then settled in the bank of Indus and its tributary rivers. The entered Phagal and then came in Bahawalpur and then other districts. ${ }^{17}$ Their history is well known. They came in the district from Sindh during the period of Summas. Later on many other tribes of Rajput came from Rohtak, Karnal and Gurdaspur to the district. Many other groups of Jats also mixed in Rajput and they are thought Rajput now. The Rajputs who have migrated from Rohtak belong 
Vol. II, Issue 3, Oct - December 2021

ISSN No: (ONLINE): 2710-043

www.irjei.com
International Research Journal of Education and Innovation

ISSN No: ISSN (PRINT): 2710-0448

DOI: https://doi.org/10.53575/irjei.v2.03(21)2.15-34

Socio-cultural Condition of South Punjab: A Case of Muzaffargarh District

to Panwar group of Rajput. In the independence war they played vital role against the British army service is their first choice. A Rajput of Rohtak shot major Neel dead in 1887. Mount Stewart Elphinstone said that the Rajputs belonged to the Lunar and Solar races.18 In the district large numbers of them are agriculturist now. Some main branches of Rajputs are Daha, Rangar, Dogar, Chohan, Joyah, Gujar, Bhatti, and Panwar It is said that the Bloches are belonged to sametic race. They came from Makran to Dera Ghazi khan and then they advanced to the district. Mir Jalal khan was the chief and ruler of all the Bloach. He left four sons, Rind, Lashar, Hot and Korai and a daughter Jatto from whom the Rind, Lashari, Hot, Korai and Jatoi tribes. Bloch had their splendid past when they were remained the ruler of Dera Ghazi Khan for 200 years. ${ }^{19}$ The Bloch have a strong hold in Tahsil Alipur and they decrease from south to north. The first group of the Bloach tribe was Bloch Chandia who came to district earlier. Their traditions and customs are very different from Jats and other tribes of the district. But now they have mixed with others tribes. The Bloach tribes are large in numbers and they are different from each other. But the common bond is the name of Bloach.In the district the Bloches are not different from the others tribes. Their language is Sraiki now. The major branches of Bloches are Dasti, Jatoi, Mastoi, Sakhani, Ghazlani, Gurmani, Pitafi, chandia, Surhani. In the district Dasti tribe is politically powerful. Earlier Sardar Abdul Hameed Khan Dasti the great Muslim lawyer of the district, vice chairman of district board, Founder of Anjman-e-Islamia, President District National war front, president Punjab Red crescent. He worked very hard for the welfare of the Muslim in the district before the creation of Pakistan. After 1947 to 1958 he always remained as a minister in every provincial government. He also remained a Chief Minister of West Pakistan.20 His son Sardar Amjad Hameed Khan Dasti elected MPA seven times. It shows that the Muzaffargarh city is under the total control of Dasti tribe. ${ }^{21}$ The other tribe of the district is Jhabels.It is said that this tribe belongs to Sindh and they came from Sindh and that's why they speak pure Sindhi.We don't know about their arrival. They are also called Jam. They live near the river. They live mainly by fishing and making basket. Some of them have taken to agriculture. They are mostly live in the tehsil Alipur and in the southern area of tehsil Muzaffargarh. They are thought and counted good Muslims. It is said that both these are same. Kihals and Mores are one tribe. In the North side of the district they are called MOR, they eat Crocodiles, tortoises and many others reptiles. That s why the Muslims don't associate with them. In South they are called Kihals and don't eat reptiles. Kihals considered good Muslims. If we look their life they live near the river. They live by fishing but some of them have taken to agriculture now. ${ }^{22}$

Yed are also a major caste in the district. They are thought as a religious leader of the people in the district. It is also thought they are the superior caste than the others. They do not give their daughter as married to the other castes or tribes except Syeds or Queshis. Their main branches are Bukhari, Naqvi, Rizvi, Kazmi, Mashahdi, zaidi and Gillani. ${ }^{23}$ The other important tribe in the district is Qureshi. Mostly they are landlord in the district. They were respected in the different governments, especially in the days of Dewan Sawan Mal. It is said that they are the representative of symatic race mostly they are in the District. They are thought superior then other tribes and races. They keep shrines and tombs as a religious institute. They do not give there daughter as married to the other castes or tribes except Syeds or Quashes.24 Pathan introduced during period of Multani rule. When Multan was under the 
Vol. II, Issue 3, Oct - December 2021

ISSN No: (ONLINE): 2710-043

www.irjei.com
International Research Journal of Education and Innovation

ISSN No: ISSN (PRINT): 2710-0448

DOI: https://doi.org/10.53575/irjei.v2.03(21)2.15-34

\section{Socio-cultural Condition of South Punjab: A Case of Muzaffargarh District}

Sadozais.Nawabzada Saif Ullah Khan and his son Nawabzada Nasar Ullah are very important and famous Pathan personalities of the district. Jat and Bloch are the most dominant Multan was under the Sadozais.Nawabzada Saif Ullah Khan and his son Nawabzada Nasar Ullah are very important and famous Pathan personalities of the district. Jat and Bloch are the most dominant tribes in the district as shown in the table.

\begin{tabular}{|l|l|l|l|l|l|}
\hline Sr.No & Caste & 1881 & 1891 & 1901 & 1921 \\
\hline 1 & Jat & 109352 & 105378 & 117362 & 211191 \\
\hline 2 & Bloach & 58399 & 68346 & 76586 & 108413 \\
\hline
\end{tabular}

Mostly populations of the tribes are professing Sunni (Brailvi) faith. The people of the district are Pir minded. Visit to the shrines of saints are very common. In the district every persons have their own Peer and he try to follow his teaching. He takes oath to follow his Pir and it is called "Bayat". Bayat is a contract between the Pir and the Murid that the Murid will always be remain faithful of his Pir. ${ }^{26}$ Hazrat Din Panah, Hazrat Alam shah Bukhari, Hazrat Pir Jahanian Hazrat Ghous Hamza are very famous saints. The Urs of these saints are held annually at their shrines.

The language, which is spoken in the district, it is called Jtaki in the local words. The language was called Multani, Riasti and Lehnda also. After the creation of Pakistan the language called Punjabi as shown in the census reports. But in 1961 the scholars of this language decided in a meeting that the undisputed name of this language is Saraiki, there fore the language is now called Saraiki. The $90 \%$ population speaks Saraiki and the $86 \%$ people used it as a mother tongue. Saraiki is the predominant langue being spoken in the district. It representing 86.percent of the total population, followed by Punjabi, Urdu, Blochi, Pushto, Sindhi, Brahvi, Anddari etc. The people who speak Urdu, Punjabi and Pushto are urban than rural area. ${ }^{27}$

\begin{tabular}{|c|c|c|c|c|c|c|c|}
\hline Year & Eng & Bengali & Punjabi & Sindhi & Urdu & Blochi & Pushto \\
\hline 1951 & 01 & 06 & *690043 & 08 & 60933 & 10 & 244 \\
\hline 1961 & 04 & 23 & *943559 & 89 & 44250 & 205 & 1678 \\
\hline 1981 & - & - & $13 \%$ & - & $4.4 \%$ & - & $0.9 \%$ \\
\hline Year & Persian & Arab & \multicolumn{3}{|c|}{ Other } & \multicolumn{2}{|c|}{ Sraiki } \\
\hline 1951 & 01 & 03 & \multicolumn{3}{|c|}{ Brahui } & \multicolumn{2}{|c|}{-} \\
\hline 1961 & 27 & - & \multicolumn{3}{|c|}{25} & \multicolumn{2}{|c|}{-} \\
\hline 1981 & - & - & \multicolumn{3}{|c|}{-} & \multicolumn{2}{|c|}{$80.5 \%$} \\
\hline
\end{tabular}

Without Khawaja Ghulam Farid Saraiki language and literature is not complete. He is the well known poet and scholar of the Saraiki language. ${ }^{28}$ The main occupation of the people of the rural areas is agriculture. Some other important occupations are like the ban making, Baskets, Ropes, Mats of date-palm leaves of the occupation of the men, while the women and children are also assist the males in their agricultural and the other means of livelihood. There fore the agriculture and the other cottage industries are very much important for their livelihood. ${ }^{29}$

- The stockbreeding is also an important occupation of large number of people. Because good cattle are very necessary to the people's requirement.

- Large numbers of people are workers and they are also engaged in trading occupation. The strength of the people in this profession is increasing very rapidly. 
Vol. II, Issue 3, Oct - December 2021

ISSN No: (ONLINE): 2710-043

www.irjei.com
International Research Journal of Education and Innovation ISSN No: ISSN (PRINT): 2710-0448 DOI: https://doi.org/10.53575/irjei.v2.03(21)2.15-34

Socio-cultural Condition of South Punjab: A Case of Muzaffargarh District

- Money-lendig is also a most important occupation of the district. In this profession bankers, insurance agent, Moneychangers Brokers.

- Some people following trade in the textile, wood, furniture, metals, building materials, pottery and much kind of articles to earn their livelihood. ${ }^{30}$

Important Service Occupations

\begin{tabular}{|c|c|c|c|c|c|c|c|}
\hline Year & $\begin{array}{c}\text { Engineer } \\
\text { Architect }\end{array}$ & $\begin{array}{c}\text { Office } \\
\text { Worker }\end{array}$ & $\begin{array}{c}\text { Railway } \\
\text { worker }\end{array}$ & $\begin{array}{c}\text { Police\& } \\
\text { Fire } \\
\text { service }\end{array}$ & $\begin{array}{c}\text { Professor } \\
\text { Teacher }\end{array}$ & Physicians & $\begin{array}{c}\text { Health } \\
\text { worker }\end{array}$ \\
\hline 1929 & - & 1784 & 03 & 06 & - & - & - \\
\hline 1951 & 06 & 3004 & 10 & 387 & 246 & 160 & 75 \\
\hline 1981 & 11 & 6222 & 45 & 992 & 1768 & 327 & 134 \\
\hline
\end{tabular}

\begin{tabular}{|c|l|l|l|l|l|l|l|}
\hline $\begin{array}{l}\text { Yea } \\
\text { r }\end{array}$ & $\begin{array}{l}\text { Busine } \\
\text { ss } \\
\text { executi } \\
\text { ve }\end{array}$ & $\begin{array}{l}\text { Sales } \\
\text { Workers\& } \\
\text { Shopkeeper }\end{array}$ & $\begin{array}{l}\text { Unski } \\
\text { lled } \\
\text { work } \\
\text { ers }\end{array}$ & $\begin{array}{l}\text { Domest } \\
\text { ic } \\
\text { worker } \\
\text { s }\end{array}$ & $\begin{array}{l}\text { Other } \\
\text { service } \\
\text { workers }\end{array}$ & $\begin{array}{l}\text { Transport } \\
\text { manager\& } \\
\text { Pilots }\end{array}$ & $\begin{array}{l}\text { Road } \\
\text { Transport } \\
\text { er }\end{array}$ \\
\hline $\begin{array}{c}195 \\
1\end{array}$ & 778 & 4989 & 25066 & 3351 & 2031 & - & 1289 \\
\hline $\begin{array}{c}198 \\
1\end{array}$ & 2667 & 13078 & 57000 & 23000 & 7426 & - & 5729 \\
\hline
\end{tabular}

Agricultural\& Related Labour

\begin{tabular}{|l|l|l|l|l|l|l|c|}
\hline Year & $\begin{array}{l}\text { Labou } \\
\mathbf{r}\end{array}$ & $\begin{array}{l}\text { Cultivato } \\
\mathbf{r}\end{array}$ & $\begin{array}{l}\text { Herdsmen\& } \\
\text { Animal } \\
\text { Breeders }\end{array}$ & $\begin{array}{l}\text { Other } \\
\text { Breede } \\
\text { r }\end{array}$ & $\begin{array}{l}\text { Hun } \\
\text { ter }\end{array}$ & $\begin{array}{l}\text { Dairy\& } \\
\text { Poultry } \\
\text { Keeper }\end{array}$ & $\begin{array}{l}\text { Orchard } \\
\text { Nurseries } \\
\text { men }\end{array}$ \\
\hline 1951 & $\begin{array}{c}17080 \\
4\end{array}$ & 163356 & 3679 & - & - & 130 & - \\
\hline 1961 & $\begin{array}{c}21235 \\
5\end{array}$ & 224437 & 9037 & 02 & 08 & 103 & 333 \\
\hline
\end{tabular}

\begin{tabular}{|l|l|r|r|c|l|l|}
\hline Year & Bees Keeper & $\begin{array}{r}\text { Silk-worm } \\
\text { Keeper }\end{array}$ & $\begin{array}{r}\text { Driver } \\
\text { Tractor }\end{array}$ & $\begin{array}{r}\text { Unemploy } \\
\text { ed }\end{array}$ & Malis & $\begin{array}{l}\text { Market } \\
\text { Gardener }\end{array}$ \\
\hline 1951 & 523 & - & - & 1566 & 1550 & - \\
\hline 1961 & 15 & 12 & 59 & - & 426 & 42 \\
\hline
\end{tabular}

People Engaged Different Occupations

\begin{tabular}{|c|c|c|c|c|}
\hline Sr. No & Occupation & Males & Females & Dependants \\
\hline 1 & Pasture\& Agriculture & 114797 & 2620 & 244720 \\
\hline 2 & Fishing\& Hunting & 550 & 08 & 675 \\
\hline 3 & Textile & 5073 & 2174 & 9382 \\
\hline 4 & Wood & 4123 & 129 & 8544 \\
\hline 5 & Ceramics & 3038 & 41 & 6237 \\
\hline
\end{tabular}


Vol. II, Issue 3, Oct - December 2021

ISSN No: (ONLINE): 2710-043

www.irjei.com
International Research Journal of Education and Innovation ISSN No: ISSN (PRINT): 2710-0448 DOI: https://doi.org/10.53575/irjei.v2.03(21)2.15-34

Socio-cultural Condition of South Punjab: A Case of Muzaffargarh District

\begin{tabular}{|c|c|c|c|c|}
\hline \hline 6 & Industries & 8458 & 198 & 17848 \\
\hline 7 & Transport & 4757 & 10 & 9099 \\
\hline 8 & Trade in Goods & 3192 & 465 & 7644 \\
\hline 9 & Trade of other sorts & 9291 & 98 & 20455 \\
\hline 10 & Religion & 1339 & 68 & 3283 \\
\hline 11 & Domestic service & 2101 & 86 & 3092 \\
\hline 12 & Others & 9442 & 1142 & 18522 \\
\hline 13 & Beggars & 6185 & 1098 & 9525 \\
\hline
\end{tabular}

Worker of different Occupations

\begin{tabular}{|l|l|l|l|l|}
\hline Year & Manufacturing & $\begin{array}{c}\text { Trade\& } \\
\text { Commerce }\end{array}$ & $\begin{array}{c}\text { Govt. \&Municipal } \\
\text { Services }\end{array}$ & \multicolumn{1}{c|}{$\begin{array}{c}\text { Domestic\& } \\
\text { Personal Services }\end{array}$} \\
\hline 1951 & $12000 \quad 22 \%$ & $6000 \quad 11 \%$ & $3000 \quad 05 \%$ & $5000 \quad 09 \%$ \\
\hline Year & Metal & Wood & Glass Ceramics & Leather \\
\hline 1951 & 1387 & 1818 & 1298 & 2601 \\
\hline
\end{tabular}

Economically Active Population

\begin{tabular}{|l|l|l|l|l|l|l|l|l|}
\hline Year & \multicolumn{2}{|l|}{ Land Owner } & Agricultural & Defense & $\begin{array}{l}\text { Forestr } \\
\mathrm{y}\end{array}$ & Fisheries & Manufacturing Building \\
\hline 1951 & \multicolumn{2}{|l|}{$\begin{array}{l}103976 \\
101816\end{array}$} & \multicolumn{2}{|c|}{02} & - & - & \multicolumn{1}{c|}{480} \\
\hline Year & Trade & $\begin{array}{l}\text { Transporter } \\
\text { shipping }\end{array}$ & $\begin{array}{l}\text { Govt. } \\
\text { Service }\end{array}$ & $\begin{array}{l}\text { Other } \\
\text { professions }\end{array}$ & $\begin{array}{l}\text { Imam } \\
\text { Religious }\end{array}$ & $\begin{array}{l}\text { Hakims } \\
\text { Health }\end{array}$ & Beggar \\
\hline 1951 & 786 & 110 & 475 & 27 & 38 & 102 & ---- \\
\hline
\end{tabular}

Literacy Ratio of the Distt.M.Garh

\begin{tabular}{|c|l|c|c|c|c|}
\hline Year & \multicolumn{1}{|c|}{ District M.Garh } & $\begin{array}{l}\text { Tehsils } \\
\text { Alipur }\end{array}$ & M.Garh & Kotadu & Layyah \\
\hline 1901 & $03.6 \%$ & - & - & - & - \\
\hline 1931 & $07 \%$ & - & - & - & - \\
\hline 1951 & $\begin{array}{l}16.2 \% \\
\text { M-8.0\% F-14.4\% }\end{array}$ & - & - & - & - \\
\hline 1961 & $8.12 \%$ & $5.77 \%$ & $7.33 \%$ & $9.93 \&$ & $9.80 \%$ \\
\hline 1972 & $\begin{array}{l}11.3 \% \quad---- \\
\text { M-18.1\% F-4.2\% }\end{array}$ & ---- & --- & -- \\
\hline 1981 & $\begin{array}{l}16.8 \% \text { M- } 25.8 \% \text { F- } \\
06.3 \%\end{array}$ & $12.1 \%$ & $15.9 \%$ & $19.4 \%$ & $18.9 \%$ \\
\hline
\end{tabular}

Students of all Nations on 31 ${ }^{\text {st }}$ March 1929

\begin{tabular}{|c|c|c|c|c|c|c|}
\hline Caste & \multicolumn{2}{|c|}{ High School } & \multicolumn{2}{c|}{ Others Schools } & \multicolumn{2}{c|}{ Total } \\
\hline & 1929 & 1906 & 1929 & 1906 & 1929 & 1906 \\
\hline Brahmins & 49 & 20 & 191 & 71 & 240 & 91 \\
\hline Non-Muslims & 1129 & 170 & 5503 & 1178 & 6632 & 1348 \\
\hline Sikhs & 19 & 14 & 92 & 19 & 111 & 33 \\
\hline Muslims & 683 & 117 & 17109 & 1437 & 17792 & 1554 \\
\hline
\end{tabular}


Vol. II, Issue 3, Oct - December 2021

ISSN No: (ONLINE): 2710-043

www.irjei.com
International Research Journal of Education and Innovation

ISSN No: ISSN (PRINT): 2710-0448

DOI: https://doi.org/10.53575/irjei.v2.03(21)2.15-34

Socio-cultural Condition of South Punjab: A Case of Muzaffargarh District

\begin{tabular}{|c|c|c|c|c|c|c|}
\hline Others & 3 & 3 & 233 & 11 & 236 & 14 \\
\hline Total & 1883 & 324 & 23128 & 2716 & 23011 & 3040 \\
\hline
\end{tabular}

Anjman-e-Islamia Muzaffargarh established Muslims Hostel and Islamia School. The Anjman worked for the education of the poor Muslims. It was very popular among the Muslims. ${ }^{31}$ In 1933 there were 133 primary schools in the district, in these 133 schools 127 were under district board and 6 were under committees. After the establishment of Pakistan many schools were established and in 1961 the literacy ratio was round about 14\%. In 1964 the district rank was 29 in West Pakistan of education. ${ }^{32}$

\section{Educational Institutes}

\begin{tabular}{|l|c|c|c|c|c|}
\hline Institutes & $\mathbf{1 8 8 1}$ & $\mathbf{1 9 5}$ & $\mathbf{1 9 6 1}$ & $\mathbf{1 9 7 2}$ & $\mathbf{1 9 8 1}$ \\
\hline Degree College & - & - & 01 & - & 04 \\
\hline Intermediate college & - & - & 04 & 03 & 03 \\
\hline Professional college & - & & 01 & 01 & 03 \\
\hline High School & 01 & 03 & 14 & 20 & 68 \\
\hline Middle school & 86 & & 28 & 114 & 266 \\
\hline Primary School\&*Vernacular & 58 & 282 & $621 \&^{*} 113$ & 1268 & 3084 \\
\hline Special School / Normal & 01 & & $25 \& * 01$ & - & - \\
\hline Advanced/ Poly Tech. & 14 & & $* 01$ & - & - \\
\hline
\end{tabular}

According to the district gazetteer 1908, in1901 3677 Muslims were literate out of 350177 Muslims population, only 119 females were literate out of 3677.In 1905 Muzaffargarh high school was the single high school of the district. And there were 319 students in it. Middle school had 132 students, a vernacular school had 189 students and 60 primary schools had 2296 students. There were 4 girl's primary schools and the students were 120.33

In 196130 persons were postgraduate 20 males and 10 females, 283 persons were graduate 261 males and 22 females.4808 persons were Matric pass 4586 males and 226 females. Middle pass were 12659 males were 11650 and females were 1009, while primary pass were 26744, males were 24691 and females 2554 .0nly 99 persons were law graduates. In district numbers of high schools were 10, middle schools 23 and primary schools were 505.34

Professional Degrees\& Diploma Holders were as under;

\begin{tabular}{|c|l|l|c|c|c|c|c|}
\hline Year & Education & Medical & Law & Engg. & Agri. & Commerce & Others \\
\hline 1961 & T-2097 & 293 & 99 & 252 & 187 & 27 & 93 \\
& M-1922 & 281 & 99 & 251 & 171 & 27 & 93 \\
& F- 175 & 12 & 0 & 01 & 16 & & 0 \\
\hline 1981 & 2671 & 253 & 545 & 1451 & 294 & 445 & 120 \\
\hline
\end{tabular}

35

Enrolment of students

\begin{tabular}{|c|c|c|c|c|c|}
\hline Year & primary & Middle & Matric & $\begin{array}{l}\text { Inter\& } \\
\text { Degree }\end{array}$ & Higher Degree \\
\hline 1951 & $22184 * 3300$ & 7232 & 2221 & 46834 & 131 \\
\hline
\end{tabular}


Vol. II, Issue 3, Oct - December 2021

ISSN No: (ONLINE): 2710-043

www.irjei.com
International Research Journal of Education and Innovation

ISSN No: ISSN (PRINT): 2710-0448

DOI: https://doi.org/10.53575/irjei.v2.03(21)2.15-34

Socio-cultural Condition of South Punjab: A Case of Muzaffargarh District

\begin{tabular}{|c|c|c|c|cc|c|}
\hline \hline & & 699 & 96 & & 08 \\
\hline 1961 & $24691 * 2554$ & 11650 & 4586 & 871 & 95 & 200 \\
& & 1009 & 226 & & & 10 \\
\hline 1981 & $24632 * 6978$ & 11725 & 5500 & 2103 & 400 & 958 \\
& & 2251 & 1577 & & & 144 \\
\hline
\end{tabular}

Scholarships 1929

\begin{tabular}{|c|l|c|c|c|}
\hline Sr. \# & Kind Of Scholarship & $\begin{array}{c}\text { No. of } \\
\text { Scholarships }\end{array}$ & Amount & Sources \\
\hline 1 & Open & 24 & 4 Rs. & District Board \\
\hline 2 & Close & 40 & 4 Rs. & District Board \\
\hline 3 & Victoria & 44 & 4 Rs. & District Board \\
\hline 4 & $\begin{array}{l}\text { Khan Bahadur Kaure Khan } \\
\text { Jatoi }\end{array}$ & 20 & 4 Rs. & $\begin{array}{c}\text { Khan Bahadur Kaure } \\
\text { Khan }\end{array}$ \\
\hline 5 & $\begin{array}{l}\text { Khan Bahadur Makhdom } \\
\text { Ghulam Qasim Hailey Wala }\end{array}$ & 1 & 10 Rs. & $\begin{array}{c}\text { KhanBahadur } \\
\text { Makhdom Ghulam } \\
\text { Qasim Estate }\end{array}$ \\
\hline 6 & Military & 6 & $\begin{array}{l}4-8 \text { Rs. 2- } \\
\text { 2Rs. }\end{array}$ & \begin{tabular}{c} 
Provincial Fund \\
\hline
\end{tabular} \\
\hline
\end{tabular}

\section{Scholarships1964}

\begin{tabular}{|l|l|l|l|l|}
\hline $\begin{array}{l}\text { Sr. } \\
\text { No. }\end{array}$ & $\begin{array}{l}\text { Kind Of } \\
\text { Scholarship }\end{array}$ & $\begin{array}{l}\text { Numbers of } \\
\text { Scholarships }\end{array}$ & $\begin{array}{l}\text { Amount } \\
\text { Rs. }\end{array}$ & Sources \\
\hline 1 & Residential & 7 & 20 P.m & Provincial \\
\hline 2 & Non- Residential & 15 & 50 & Provincial \\
\hline 3 & Open & 28 & 4 P.m & District Council fund \\
\hline 4 & Kaure Khan Jatoi & 5 & 4 P.m & District Council fund \\
\hline 5 & Depressed class & 1 & 4 P.m & District Council fund \\
\hline 6 & $\begin{array}{l}\text { Military } \\
\text { Scholarships }\end{array}$ & 2 & 4 P.m & District Council fund \\
\hline
\end{tabular}

People wear different type of dress in different areas. The headdress of men in the plain areas is called turban and they wear pajama and a piece of cloth, which is called Dhoti. But in the urban areas the people especially among those who are leading the official life they wear pent and shirt in the office. Some people wear Kurta it is a loose and wide shirt and it is reaching up to the knees. In the cold winter waist coat or a loose coat wadded with cotton was worn. A pair of shoes completes the working day dress of a farmer. A Chadar or a Lungi is also carried on the shoulder. The women used Bochan (Dopatta) as head dress, a shirt (Chola) of short length and a Ghghra (skirt like dress). The usual dress of a boy is Chadar, Chola and Ghaggra or Shalwar. The festival dress of a man consists of colored Pagri, Shirt and Manjhla. The women use clothes of bright colour. But with the time lot of changes were seen in the people, $s$ dress in villages and towns. In the towns people used the cloth manufactured in west countries, like as pent shirts. The women of the district are very fond of the jewellery. There 
Vol. II, Issue 3, Oct - December 2021

ISSN No: (ONLINE): 2710-043

www.irjei.com
International Research Journal of Education and Innovation

ISSN No: ISSN (PRINT): 2710-0448

DOI: https://doi.org/10.53575/irjei.v2.03(21)2.15-34

Socio-cultural Condition of South Punjab: A Case of Muzaffargarh District

are different type of jewellery were known in the district. Such kind of ornaments is for the arms, wrists, fingers, feet, nose, ears, neck, head and ankles. The jewellery was invariably made of the gold and silver. The worn of jewellery is depends on the financial condition of the people. The most valuable ornament is a gold Necklace. In some areas of the district men also show any link for jewellery and they also content to wear a ring or pear of earing. ${ }^{36}$

Fairs are also important recreations among the villagers of the district. That's why religious festivals and Mealas are also held in the district. Such kinds of mealas are called Urs. Many fairs are held in the district Muzaffargarh .A village fair is held $s$ at the shrine of Hazrat Daud Jahanian at the distance of three miles away from south of Muzaffargarh who is a famous saint of the district and is known as the name of Pir Jahanian. The fair is usually holds in the months of Chet and Sawan on every Thursday. Large numbers of visitor are come from the adjoining districts and the local district. They devotees offer fatiha and give their Vow (Mant) after achieving their goals. They bring a Sheep to cook and $20 \mathrm{~kg}$ Flour to make bread, which is distributed among the poor. This kind of Vow (Mant) is called Atta-Ghatta in the local language. Large numbers of visitor are come from the adjoining districts and the local district. They devotees offer fatiha and give their Vow (Mant) after achieving their goals. They bring a Sheep to cook and $20 \mathrm{~kg}$ Flour to make bread, which is distributed among the poor. This kind of Vow (Mant) is called Atta-Ghatta in the local language. ${ }^{37}$ Another fair is held at the shrine of Hazrat Sheikh Mohammad Tahir known as Hazrat Bagga Sheer in the village of Khanpur which is located at the distance of $6^{\text {th }}$ miles from the Muzaffargarh. This fair is held on every Monday in the months of Sawan and Bhadon. Another famous Urs is held at the shrine of Hazrat Abdul Ullah Shah. A large numbers of devotees are attracted to come at the shrine near the Muzaffargarh. A fairs is also held at the shrines of Hazrat Mohib Jahanian in the village Haji Metla and a very important fair is held at the shrine of Hazrat Lal Eason at Karor to pay homage to this famous saint, The fair is continue about 10 days in the month of August. An other very famous fair held at the shrine of Hazrat Din Panah at Daira Din Panah from Monday to Sunday in the Month of Har to Bhadon. ${ }^{38}$ In the rural areas of the district Hukka is very common. People sit with each other and they are habitual of smoking hukka. It is placed at a common place and the surrounding people get round it. It is made with fresh water and the earthen cap with Tobacco under fire is placed on it. They talk light thing, make gupshup and convey news to one another. It refreshes them and prepares them for further work.

The people of the district are very fond of sports and games. The children play many kinds of games especially some local games are very popular in the district rural areas. They play a Gitti Danda or tip- cat; Kabadi, Chidde (marble) and hide seek in the village while the boys of towns and cities play Cricket, football, Voli-ball and hockey. The girls play Sheend, Dolls usually. But they are deprived from the modern games due to the strict traditions of the society. ${ }^{39}$

Muzaffargarh has a much literary taste. It has unique place in the literature. Lot of scholars and poets were born in the district. Such of them Kaure Khan, Kushfi Multani, Maher Abdul Haq, Abdul Aziz Pirharvi. Janbaz Jatoi and Naseem of Layyah. Muzaffargarh is a fertile land of literature. It is mentioned in Multan Nama that there were many Hindus poet and they belonged to district Muzaffargarh. They served the literature very nicely till migration. Dalu Ram Moji was born in Khairpur Sadat tehsil Alipur in 1880. His one of famous verse was as, 
Vol. II, Issue 3, Oct - December 2021

ISSN No: (ONLINE): 2710-043

www.irjei.com
International Research Journal of Education and Innovation

ISSN No: ISSN (PRINT): 2710-0448

DOI: https://doi.org/10.53575/irjei.v2.03(21)2.15-34

Socio-cultural Condition of South Punjab: A Case of Muzaffargarh District

\section{Nohrin ajkal neak Sdavin}

Shore mchavin Lok Khilavin
Nal suson de Jherey Lavin

Akhin das tun kia khawa,ay

Atan Chand Sadhu Lal was born in 1899 at Banda ishaq. He had great relation to the Muslims and often come to the poetry Majlis. One of his famous verse is,

\section{Ay Malik Tu Karam Krin Men Ayeb Kitin Ghari Ghari}

Besides these Lachanas Tabasum Aliuri and Shabab Lalat of Khangarh were very famous poets of the district. All these had a special place in the literature. ${ }^{40}$ It is said that music is the food of soul. The common people sing Kafies of Khawajah Farid and the Dorhas (Saraiki songs) of the local poets in a shrill voice and in sad tune. The most popular poet of the district is the Classical Saraiki poet and a famous saint Khawajah Ghulam Farid of Kot Mithon. ${ }^{41}$ Education has improved and many women are come forward and elected as member of local councils as well as provincial assembly and national assembly like Mohtrma Tehmina Dasti. Khalida Mohsin Qureshi and Hina Rabbani Khar are most famous. In the district the registration of the vehicles had started in 1940.according to the information of excise and taxation office there were only 24 registered vehicles in 1947 and they were increased up to 35 in April 1948. Now there are more than 40 thousand registered vehicles in the district. 42 Some famous persons who had vehicle before Pakistan

\begin{tabular}{|l|l|l|}
\hline Sr.No & Name & Vehicle \\
\hline 1 & Khan Abdul Hameed Khan Dasti & Car \\
\hline 2 & Mian Mushtaq Ahmad Gurmani & Car \\
\hline 3 & Mian Ghulam Jellani Gurmani & Car \\
\hline 4 & Manzor Hussain Rangpur & Car \\
\hline 5 & Habib Ullah Khan & LTV \\
\hline 6 & Major N.A Qureshi (surgeon) & Car \\
\hline 7 & Sh.Abdul Hameed (SDO) & Car \\
\hline 8 & Syed Niaz Hussain D.C & Car \\
\hline 9 & Sh. Isahaq Elahi (D.E) & Car \\
\hline 10 & Malik Mohammad Yar Khar & Car \\
\hline 11 & K.B Mohammad Hussain Hon. Magistrate Seetpur & Car \\
\hline 12 & Khalil Ahmad Shah & Car \\
\hline 13 & Mian Ijaz Ahmad PAS & Car \\
\hline 14 & Sh.Ghulm Mohammad & Car \\
\hline 15 & Niaz Ahmad Gurmani & Car \\
\hline
\end{tabular}

Sardar Kaure Khan Jatoi S/o Sardar Said Khan Jatoe devoted his property for the well fare of the people. It was 10344 acres, which was transferred to district board in 1897.This property, was 3/9 of his total property. Last will was written on $05-10-1884$.He was died on 15-051896. The property was consisted on irrigation system and it remained on lease till 1960.In 1961-62 district council divided this property in 247 lots and each lot was consisted on 400 canals. ${ }^{43}$

Detail of Sardar Kaure Khan, s Property 1-Lots district Muzaffargarh

\begin{tabular}{|c|c|c|c|c|}
\hline Sr. No. & Moza & Tehsil & No. Of Lots & Area (Kanal) \\
\hline 1 & Qaisar Ghazlani & Jatoi & 3 & $69-3$ \\
\hline
\end{tabular}


Vol. II, Issue 3, Oct - December 2021

ISSN No: (ONLINE): 2710-043

www.irjei.com
International Research Journal of Education and Innovation ISSN No: ISSN (PRINT): 2710-0448 DOI: https://doi.org/10.53575/irjei.v2.03(21)2.15-34

Socio-cultural Condition of South Punjab: A Case of Muzaffargarh District

\begin{tabular}{|c|c|c|c|c|c|c|c|}
\hline 2 & \multicolumn{2}{|c|}{ Jatoi Gharbi } & \multicolumn{2}{|c|}{ do } & 7 & \multicolumn{2}{|c|}{$545-15$} \\
\hline 3 & \multicolumn{2}{|c|}{ Jatoi Shumali } & \multicolumn{2}{|c|}{ do } & 35 & \multicolumn{2}{|c|}{ 2259-1 } \\
\hline 4 & \multicolumn{2}{|c|}{ Rao } & \multicolumn{2}{|c|}{ do } & 2 & \multicolumn{2}{|c|}{ 198-5 } \\
\hline 5 & \multicolumn{2}{|c|}{ Beat Sulaiman } & \multicolumn{2}{|c|}{ do } & 2 & \multicolumn{2}{|c|}{$53-12$} \\
\hline 6 & \multicolumn{2}{|c|}{ Sahu } & \multicolumn{2}{|c|}{ do } & 1 & \multicolumn{2}{|c|}{$2-15$} \\
\hline 7 & \multicolumn{2}{|c|}{ Wadu Wala } & \multicolumn{2}{|c|}{ do } & 2 & \multicolumn{2}{|c|}{$214-9$} \\
\hline 8 & \multicolumn{2}{|c|}{ Chak Wala } & \multicolumn{2}{|c|}{ do } & 1 & \multicolumn{2}{|c|}{$160-7$} \\
\hline 9 & \multicolumn{2}{|c|}{ Mir Wala } & \multicolumn{2}{|c|}{ do } & 4 & & \\
\hline 10 & Mor & hi Wala & $\mathrm{dc}$ & & 15 & & $32-4$ \\
\hline 11 & Kot & a Band Ali & $\mathrm{dc}$ & & 4 & & $7-16$ \\
\hline 12 & Jhu & i Wala & $\mathrm{dc}$ & & 1 & & \\
\hline 13 & Tha & ha Chandiran & $\mathrm{dc}$ & & 4 & & \\
\hline 14 & $\mathrm{Wa}$ & ey Wala & do & & 1 & & \\
\hline 15 & Sha & bazpur & $\mathrm{dc}$ & & 1 & & \\
\hline 16 & Saic & pur & do & & 17 & & $7-11$ \\
\hline 17 & Der & Kaura Khan & do & & 45 & & $8-8$ \\
\hline 18 & Ran & pur -1 & $\mathrm{dc}$ & & 90 & & $69-3$ \\
\hline 19 & Ran & pur -2 & $\mathrm{dc}$ & & 85 & & $40-3$ \\
\hline 20 & Ran & pur-3 & do & & 84 & & $41-11$ \\
\hline 21 & Fat: & hPur Janobi-1 & $\mathrm{dc}$ & & 1 & & \\
\hline 22 & Fat: & hpur Janobi-2 & do & & 1 & & \\
\hline 23 & Dha & & do & & 1 & & \\
\hline Total & 23 & & & & 406 & & $49-3$ \\
\hline 2- Lots of I & jant & & & & & & \\
\hline Sr. No. & & Moza & Teh & & No. of Lots & & ea (Kanal) \\
\hline 1 & Bea & Ghazlani & Rajar & & 1 & & \\
\hline 2 & $\mathrm{Noc}$ & rpur & $\mathrm{dc}$ & & 1 & & \\
\hline 3 & Tau & & $\mathrm{dc}$ & & 1 & & \\
\hline 4 & $\mathrm{Rab}$ & Nasee & $\mathrm{dc}$ & & 1 & & \\
\hline 5 & $\mathrm{Kac}$ & i Bukhsh & Jam! & & 1 & & 8-17 \\
\hline 6 & Din & & $\mathrm{dc}$ & & 1 & & $3-10$ \\
\hline 7 & Gul & b Shah & $\mathrm{dc}$ & & 1 & & \\
\hline 8 & Qas & m Wala & $\mathrm{dc}$ & & 1 & & \\
\hline 9 & Kot & a Mughalan & $\mathrm{dc}$ & & 1 & & \\
\hline Total 9 & & & & & 9 & & \\
\hline \begin{tabular}{|l|} 
District \\
\end{tabular} & & No. Of Moza & No. Of Lots & & Land kanal / Mc & & Acres \\
\hline Muzaffar & $\operatorname{arh}$ & 23 & 406 & & $72149-3$ & & 9019 \\
\hline Rajan I & & 9 & 9 & & 10604-11 & & 1325 \\
\hline Tota & & 32 & 415 & & 82753-14 & & 10344 \\
\hline & & Income ChaI & of the proper & $y$ of & dar Kaure Kha & & \\
\hline & ear & & Target of rec & ver & \begin{tabular}{|l|l|} 
lease & \\
\end{tabular} & & overy \\
\hline & $61-6$ & & & & & & 5000 \\
\hline
\end{tabular}


Vol. II, Issue 3, Oct - December 2021

ISSN No: (ONLINE): 2710-043

www.irjei.com
International Research Journal of Education and Innovation ISSN No: ISSN (PRINT): 2710-0448 DOI: https://doi.org/10.53575/irjei.v2.03(21)2.15-34

Socio-cultural Condition of South Punjab: A Case of Muzaffargarh District

\begin{tabular}{|c|c|c|}
\hline $1962-63$ & 63160 & 26135 \\
\hline $1963-64$ & 63160 & 51831 \\
\hline 1964-65 & 63160 & 15708 \\
\hline 1965-66 & 63160 & 69737 \\
\hline $1966-67$ & 25600 & 41456 \\
\hline $1967-68$ & 25600 & 34141 \\
\hline 1968-69 & 25600 & 100300 \\
\hline $1969-70$ & 25600 & 35511 \\
\hline 1970-71 & 25600 & 35511 \\
\hline 1971-72 & 114900 & 40331 \\
\hline $1972-73$ & 114900 & 38154 \\
\hline $1973-74$ & 114900 & 151924 \\
\hline 1974-75 & 114900 & 335612 \\
\hline $1975-76$ & 114900 & 324241 \\
\hline $1976-77$ & 78000 & 429465 \\
\hline $1977-78$ & 78000 & 335247 \\
\hline 1978-79 & 78000 & 184000 \\
\hline $1979-80$ & 78000 & 229054 \\
\hline 1980-81 & 78000 & 114344 \\
\hline 1981-82 & 432730 & 125650 \\
\hline 1982-83 & 590000 & 258880 \\
\hline 1983-84 & 590000 & 387838 \\
\hline 1984-85 & 590000 & 305015 \\
\hline $1985-86$ & 590000 & 583559 \\
\hline 1986-87 & 590000 & 5864923 \\
\hline $1987-88$ & 1068000 & 392912 \\
\hline 1988-89 & 1068000 & 327376 \\
\hline $1989-90$ & 1068000 & 8613000 \\
\hline 1990-91 & 1068000 & 433500 \\
\hline 1991-92 & 2659000 & 1046897 \\
\hline 1992-93 & 2659000 & 746710 \\
\hline 1993-94 & 2659000 & 3095750 \\
\hline 1994-95 & 2659000 & 5051000 \\
\hline $1995-96$ & 8981000 & 4805000 \\
\hline 1996-97 & 8981000 & 5853440 \\
\hline $1997-98$ & 8981000 & 6922521 \\
\hline 1998-99 & 8981000 & 4012000 \\
\hline $1999-2000$ & 8444000 & 4803540 \\
\hline 2000-2001 & 8444000 & 9228314 \\
\hline
\end{tabular}

\section{Conclusion}

Muzaffargarh is one of the southern district of Punjab and it located between the two rivers Indus and Chenab. People of the district are mostly agrarians and simple inhabitants. There 
Vol. II, Issue 3, Oct - December 2021

ISSN No: (ONLINE): 2710-043

www.irjei.com
International Research Journal of Education and Innovation

ISSN No: ISSN (PRINT): 2710-0448

DOI: https://doi.org/10.53575/irjei.v2.03(21)2.15-34

Socio-cultural Condition of South Punjab: A Case of Muzaffargarh District

social and political life was almost simple. With agriculture different other professions were also adopted by the people while religion, language and cultural traits are almost same with minor dialectic or language. Illiteracy is also an issue in the uplift of the society. Local tradition have enough influences on the lives of the people. Sufism has also an important contribution in the social construction of the society not only but also provides the spiritual guidance for the society. The discussion is summed up with this the socio-political condition of the people improved gradually with social and political norms and people have become more aware due to education and other tools. This paper will help to research scholars and students in future for their social and political condition of the people.

\section{References}

1 Faizi Bahawalpur, Saraiki Khazana, Jhok Publisher, Multan, 2006, P.130.

2 Budh, Khair Muhammad, Tareekh Muzaffar Garh, 2006, P.29

3 District Gazetter Muzaffargarh, 1929, P.307

4-Umer Kamal Khan, Multan Langah Dor Men, Bazm-e- Saqafat, Multan, 1995,P.37

5-Abdul Ullah Malik, Masood Khadar Posh, Sang-e-Meel Publications, Lahore,1989,P.177.

6-District Muzaffargarh, Census Report, 1981.

7- District Muzaffargarh, Census Report, 1981.

8- District Muzaffargarh, Census Report, 1981.

9- District Muzaffargarh, Census Report, 1981.

10- Al-Quran, Surah Al-Hujrat, verse, 13.

11- Al-Munjad, Dictionary, P. 667.

12- Encyclopedia Britannica vol.11, p. 918.

13-District Muzaffargarh, Census Report, 1981.

14-District, Gazetteer, Muzaffargarh 1964, P. 53.

15- District, Gazetteer, Muzaffargarh 1964, P. 53.

16- District, Gazetteer, Muzaffargarh 1964,P. 54.

17- Elphinstone, History of India, London, 1889, P. 253.

18-Elphinstone, P. 253.

19-District, Gazetteer, Muzaffargarh 1964,P. 54.

20-Munir Ahmad Munir, Siyasi Utar Charhao, Interview Abdul Hameed Khan Dasti, Atish Fishan Publications, Lahore, 1989, P.135.

21- Interview Sardar Amjad Hameed Khan Dasti On 10th August 2008.

22-District, Gazetteer, Muzaffargarh 1964, P. 58.

23-District Muzaffargarh, Census Report, 1981.

24-District, Gazetteer, Muzaffargarh 1964, P .57.

25-District Muzaffargarh, Census Report, 1951.

26. E.,D.,Meclagon \& H.,A.,Roze, Punjab Mazhbi Firqo Aor Sofi Silsalo ka Encyclopedia, Translator, Yasir Jawad, Book Home publishers,Lahore,2006,P.57

27- District Muzaffargarh, Census Report, 1981.

28- Hameed Nazir , Bar-e-Saghir Men Sraiki Tahzeeb, Karachi 1995, p. 7-9.

29- District Muzaffargarh Census Report 1981.

30- District Muzaffargarh Census Report 1981.

31-Munir Ahmad Munir, P.135.

32- District, Gazetteer, Muzaffargarh 1964, P.281.

33- Pakistan Census Reports, Census Reports District Muzaffargarh, 1951, 1961, 1972, 1981

34-District Muzaffargarh Census Report, 1961. 
Vol. II, Issue 3, Oct - December 2021

ISSN No: (ONLINE): 2710-043

www.irjei.com
International Research Journal of Education and Innovation ISSN No: ISSN (PRINT): 2710-0448 DOI: https://doi.org/10.53575/irjei.v2.03(21)2.15-34

Socio-cultural Condition of South Punjab: A Case of Muzaffargarh District

District Gazetteer Muzaffargarh 1964, P.279.

35- District Muzaffargarh Census Report, 1981.-

36- District Muzaffargarh Census Report, 1961.

37 -E.,D., Meclagon \& H.,A.,Roze,P.234.

38- E.,D., Meclagon \& H.,A.,Roze,P.235.

39- District, Gazetteer, Muzaffargarh 1964,P. 60.

40- Mohammad Aslam Metla, P.308-309.

41- District, Gazetteer, Muzaffargarh 1964, P. 60.

62-District, Gazetteer, Muzaffargarh 1964, P.125.

42-Record Excise \& Taxation, District Muzaffargarh.

Interview District Excise officer Muzaffargarh.

43- Record revenue office Muzaffargarh, Jama Bandi 1895 \& Advice of Sardar Kaura Khan Jatoi. 